\title{
Aristotle and the Problem of Forgiveness ${ }^{1}$
}

\author{
Jason W. Carter
}

Abstract. In recent decades, it has been argued that the modern concept of forgiveness is absent from Aristotle's conception of $\sigma v \gamma \gamma v \omega ́ \mu \eta$ as it appears in his Rhetoric and Nicomachean Ethics. In this paper, I argue that Aristotle's view is more modern than it might appear. I defend the idea that Aristotle's treatment of $\sigma 0 \gamma \gamma v \omega ́ \mu \eta$, when seen in conjunction with his theory of ethical decision, involuntary action, and character alteration, commits him to a cognitive and emotional theory of forgiveness that is both well grounded, and thoroughly modern. I go on to claim that Aristotle's view of

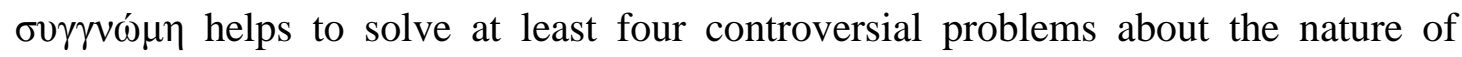
forgiveness raised by modern philosophers: how one can forgive a wrong without condoning it, whether forgiveness is a duty, whether moral luck requires us to forgive more widely, and whether forgiveness ought to be unconditional.

${ }^{1}$ I am grateful to Rufus Black and François Schroeter for their criticisms of an early draft of this paper, and to Roger Crisp, Richard Swinburne, Elena Cagnoli Fiecconi, and two anonymous referees, whose insightful comments on the penultimate draft led to this much-improved version. 
Finding Forgiveness in Aristotle. For Aristotle, forgiveness ( $\sigma 0 \gamma \gamma \nu \omega \dot{\mu \eta}){ }^{2}$ understood as the giving up of one's feeling of anger and claim to revenge against a wrongdoer, is not a virtue. ${ }^{3}$ What might have been this virtue, being $\sigma v \gamma \gamma v \omega \mu$ ovıкó , or being disposed to grant forgiveness ${ }^{4}$ - the analogue of which modern philosophers sometimes call "forgivingness" ${ }^{5}$ - is discussed only briefly. ${ }^{6}$ In the Nicomachean Ethics $(N E)$, Aristotle first describes this disposition as a deficiency in the character trait of mildness $(\pi \rho \alpha$ ó $\tau \varsigma)$, the dispositional mean between manifesting too much

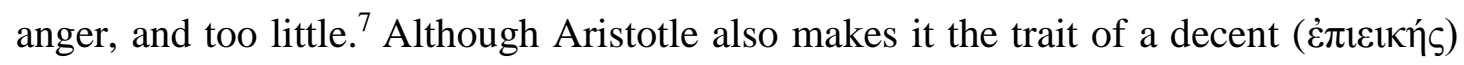

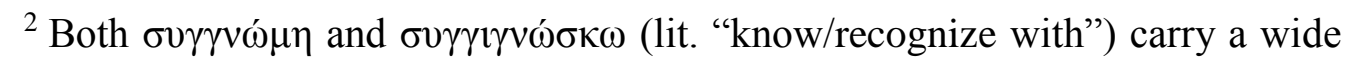
range of meanings in Greek, from "fellow-feeling," "forbearance" and "sympathetic understanding," to "pardon" and "excuse." See Henry G. Liddell, Robert Scott, Henry Stuart Jones, and Roderick McKenzie, A Greek-English Lexicon. A New (9th) edition,

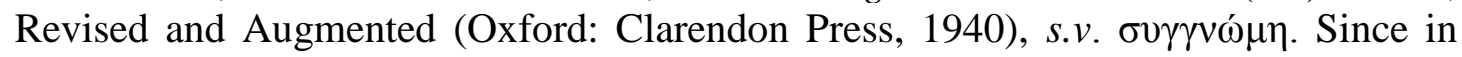
Nicomachean Ethics 3.1, 1109b30-32, Aristotle applies this term to "feelings" as well as "actions" it can be seen to include the attitude of "forgiveness," pace David Konstan, Before Forgiveness: The Origins of a Moral Idea (Cambridge: Cambridge University

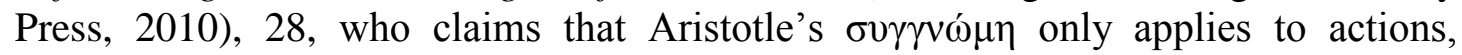
"specified as involuntary in the most strict and narrow sense of the term."

${ }^{3}$ See Rhetoric (Rhet.) 2.2, 1378a31-33, where Aristotle gives as a provisional

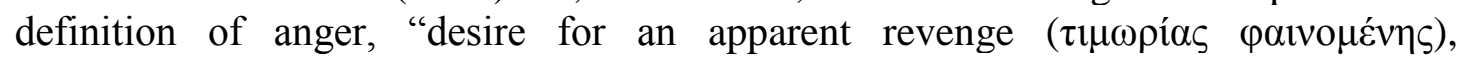

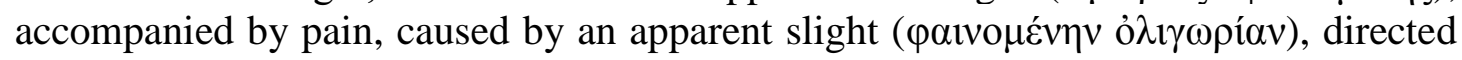
at oneself or one's friends, when the slight is unwarranted." However, in De Anima (DA) 1.1, 403a30-31, Aristotle drops $\tau 1 \mu \omega \rho i ́ \alpha$ as essential to the definition of anger, and accepts that it could be described more broadly (absent its physical conditions) as a "desire to cause irritation in return, or something of this sort (ő $\rho \varepsilon \xi 1 v \alpha \dot{\alpha} v \tau \imath \lambda v \pi \eta \dot{\sigma} \sigma \varepsilon \omega \varsigma$ ฑ $\tau 1$

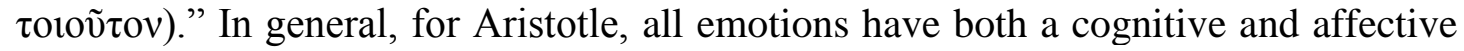
component. See Martha Nussbaum, The Therapy of Desire: Theory and Practice in Hellenistic Ethics (Princeton: Princeton University Press, 1994), 78-91, who describes Aristotelian emotions as "forms of intentional awareness." This cognitive component implies that agents cannot fully forgive wrongdoers unless they have an intelligible reason to do so.

${ }^{4}$ See Christipher Cordner, "Aristotelian Virtue and Its Limitations," Philosophy 69.269 (1994): 291-316, at 293.

${ }^{5}$ See Robert Roberts, "Forgivingness," American Philosophical Quarterly 32.4 (1995): 289-306.

${ }^{6}$ See $N E$ 4.4, 1126a3, NE 5.10, 1137a31-1138a3, NE 6.11, 1143a19-24.

${ }^{7} N E 4.4,1126 \mathrm{a} 3$. 
person, following from her virtue of considerateness $(\gamma v \omega ́ \mu \eta),{ }^{8}$ overall, he tends to value it only insofar as it inclines someone to judge what is just in situations that fall outside of the determinate scope of particular laws. ${ }^{9}$

For such reasons, in recent years Charles Griswold and David Konstan have argued that one finds in Aristotle's conception of acts of $\sigma 0 \gamma \gamma v \omega \mu \eta$ (and the classical period quite generally) only the legal notions of excusing and pardoning, acts which are only exercised rationally under the assumption that a wrongdoing agent acted in some way involuntarily. These acts are not equivalent to the modern conception of forgiveness because, as Griswold argues:

To forgive someone, by contrast, assumes their responsibility for the wrongdoing; indeed, what distinguishes forgiveness is in part that it represents a change in the moral relation between wrongdoer and wronged that accepts the fact that wrong was indeed done, and done (in some sense) voluntarily. ${ }^{10}$

In elucidating this view, Griswold outlines what he takes to be six essential conditions that a modern wrongdoer must meet in order to be forgiven. These are that the wrongdoer wishing to be forgiven must: (1) show that she no longer wishes to "stand by herself as the author of those wrongs," (2) "disavow that she would author those deeds again," (3) "experience and express regret at having caused [a] particular injury to [a] particular person," (4) "commit to becoming the sort of person who does not inflict injury," and (5) "show that she understands from the injured person's

\footnotetext{
${ }^{8} N E 6.11,1143 \mathrm{a} 19-24$.

${ }^{9}$ See $N E$ 5.10, 1137a31-1138a3.

${ }^{10}$ Charles Griswold, Forgiveness: A Philosophy Exploration (Cambridge:
} Cambridge University Press, 2007), 7. 
perspective, the damage done by the injury," and (6) "offer some sort of narrative accounting for how she came to do wrong." 11 Most of these conditions, however, he thinks are absent from Aristotle's thought.

II.

Forgiveness in Modern Philosophy. All of this suggests that Aristotle's virtue ethics may provide little help in elucidating the central problems that modern philosophers have raised about forgiveness over the past few decades. ${ }^{12}$ Among the most interesting of these problems are, first, what I shall call the Deontological Problem. On the one hand, it seems as though forgiveness must be a supererogatory or elective act, since the victim of a wrong seems to possess the right, in virtue of the fact that past actions cannot be undone, to remain angry or bestow forgiveness as she sees fit; ${ }^{13}$ on the other hand, it seems as though forgiveness must be a duty, at least in cases of repentance and restitution for harm. ${ }^{14}$ To deny this seems to rest on the idea that, in

${ }^{11}$ Griswold, Forgiveness, 49-51.

12 However, see Gregory Sadler, "Forgiveness, Anger, and Virtue in an Aristotelian Perspective," Proceedings of the American Catholic Philosophical Association 82 (2008): 229-47. That Aristotle has a theory of forgiveness is complicated even further by the fact that many of the concerns of the $N E$ are legal in nature. For this reason, one might think that we can never be sure whether Aristotle's ethical advice (e.g. on the nature of pardon and forgiveness) is meant to apply to the sphere of personal interactions, or to the law courts. However, the $N E$ itself shows that this is a false dichotomy. Aristotle thinks that whatever laws the political scientist lays down should be conducive to facilitating virtuous personal interactions. For instance, he claims that the law prescribes that citizens "do the actions of the brave person," and "the actions of the mild person, such as not to slander or strike," and in general, that it prescribes actions that accord with virtues, and proscribes actions that accord with vices (see $N E$ 5.1, 1129b19-25). Thus, since Aristotle means for his legal advice to cohere with his ethics, it is best not to see these spheres as mutually exclusive.

${ }^{13}$ See Hagit Benbaji and David Heyd, "The Charitable Perspective: Forgiveness and Toleration as Supererogatory," Canadian Journal of Philosophy 31.4 (2001): 56786, and Lucy Allais, "Wiping the Slate Clean: The Heart of Forgiveness," Philosophy \& Public Affairs 36.1 (2008): 33-68.

${ }^{14}$ See Solomon Schimmel, Wounds Not Healed by Time (Oxford: Oxford University Press, 2002), and Espen Gamlund, "The Duty to Forgive Repentant Wrongdoers," International Journal of Philosophical Studies 18.5 (2010): 651-71. 
order to merit it, a wrongdoer should perform the metaphysically impossible feat of changing the past, and it is more plausible that what a potentially forgiving agent desires is for a wrongdoer to make reparations and demonstrate moral change.

Second, and related to this problem, is Kolnai's Paradox, which suggests that, in order to avoid condoning injustice, forgiveness is only appropriate when there has been metánoia; however, when there has been metánoia, it seems there is nothing to forgive. Kolnai argues:

Either the wrong is still flourishing, the offence still subsisting: then by 'forgiving' you accept it and thus confirm it and make it worse; or the wrongdoer has suitably annulled and eliminated his offence, and then by harping on it further you would set up a new evil and by 'forgiving' you would only acknowledge the fact that you are no longer its victim. ${ }^{15}$

Third, there is what I shall call the Moral Luck Problem. This is the view that chance biological, social, or psychological conditions often (if not always) narrowly determine what sorts of decisions moral agents make. This suggests that we will often have reasons to forgive even unrepentant and vicious agents, if we can explain their viciousness as being due to some sort of moral luck. ${ }^{16}$

15 Aurel Kolnai, "Forgiveness," Proceedings of the Aristotelian Society 74 (1973/4): 91-106, at 98-9. See also Jeffrie Murphy \& Jean Hampton, Forgiveness and Mercy (Cambridge: Cambridge University Press, 1988), 41.

${ }^{16}$ See Bernard Williams, "Moral Luck," Moral Luck: Philosophical Papers 1973-1980 (Cambridge: Cambridge University Press, 1981): 20-39, who introduces the problem in terms of actions that receive their moral status retrospectively. However, it is the conception proposed by Thomas Nagel, "Moral Luck," in Mortal Questions (Cambridge: Cambridge University Press): 24-38, that I have in mind here. 
Fourth, there is what I shall call the Unconditional Forgiveness Problem. This is the question of whether it is virtuous or morally good for people to forgive wrongdoers regardless of whether they meet certain conditions, such as their apologizing or repenting for their actions. That forgiveness without conditions is either not immoral (in the sense of permissible), or moral (in the sense of good), is defended by some ethicists, and advocated by some religions. ${ }^{17}$

III.

Aristotle's Virtue Ethics and Recent Philosophy. In this paper, I shall accept Griswold's conditions on forgiveness as adequate. However, I shall argue that Aristotle's account of $\sigma v \gamma \gamma v \omega ́ \mu \eta$, once properly unpacked, contains each of these conditions, and moreover, offers a unified theoretical explanation for why they are required. For this reason, I argue, Aristotle does have a concept of forgiveness, and his explanation of its nature and the conditions in which it is rational to give it offers a plausible solution to each of the four modern problems specified above.

To show this, a few key elements of Aristotle's virtue ethics need to be explained. I first give a sketch of the two standard conditions Aristotle puts forward for an involuntary agent to be forgivable, and show how they fit into Aristotle's theory of practical reasoning (section IV). I then point out that, in a departure from the Eudemian Ethics, in the Nicomachean Ethics, Aristotle adds in a third condition for an act to count as involuntary, namely, that an agent experience pain and regret for having done it. This condition, I argue, allows Aristotle to extend forgiveness to akratic agents, despite the fact that they act voluntarily (sections V-VI). I defend the idea that Aristotle holds that

${ }^{17}$ Such an unconditional view seems implied in Cheshire Calhoun, "Changing One's Heart," Ethics 103 (1992): 76-96. It is defended at length by Eve Garrard and David McNaughton, "In Defence of Unconditional Forgiveness," Proceedings of the Aristotelian Society, 103 (2004): 39-60. See also Glen Pettigrove, "Unapologetic Forgiveness," American Philosophical Quarterly 41 (2004): 187-204. 
an ethical agent's ability to experience pain and regret is determined by her cognitiveaffective possession of what I call an "ethical universal," and it is this universal to which forgiveness responds (section VII). I then argue that, in Aristotle's discussion of the goal of virtuous friendships, he affirms the idea-crucial to the modern notion of forgiveness - that we ought to treat agents differently if their ethical character fundamentally alters. I claim that this affirmation implies that Aristotelian forgiveness can be extended even to vicious agents for their voluntary wrongs if they undergo such an alteration (section VIII).

Finally, I reconstruct Aristotle's full theory of forgiveness based on all of his ethical commitments (section IX). I go on to show that this reconstructed theory helps to solve the Deontological Problem (section X), Kolnai's Paradox (section XI), the Moral Luck Problem (section XII), and the Unconditional Forgiveness Problem (section XIII). I end by showing that the conditional theory of forgiveness that Aristotle offers helps to explain when and why we should forgive (section XIV).

IV.

Forgiveness for Involuntary Actions. Aristotle's first mention of forgiveness

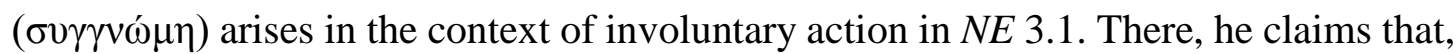

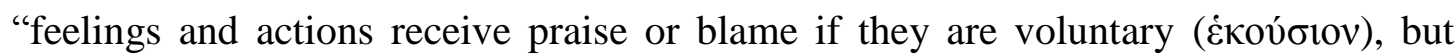

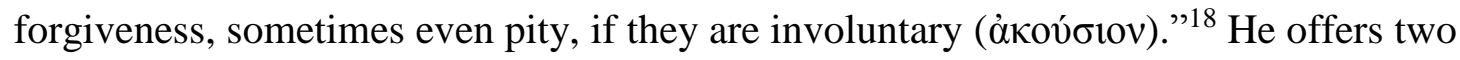
negative tests for assessing voluntariness: Something is not voluntary, he claims, if it occurs either (a) through the force of an external cause, or (b) through ignorance. ${ }^{19}$ Call

${ }^{18} N E$ 3.1, 1109b30-32.

${ }^{19}$ I here bracket the problem of Aristotle's so-called "mixed actions" discussed at $N E 3.1,1110 \mathrm{a} 5-1110 \mathrm{~b} 17$. The description of these actions initially suggests that an action can be "forced," and hence not voluntary, if it is not a choiceworthy action (or action-type) without qualification, but only choiceworthy relative to a given situation. Ultimately, however, this sense of "forced" is ruled out as a sufficient condition for judging an action to be involuntary at $1110 \mathrm{~b} 1-3$, because even in a seemingly "forced" 
the first condition the physical condition, and the second condition the ignorance condition. The physical condition is relatively easy to understand. If a person trips on the stairs and knocks you over, you might initially be angry, but you would readily forgive her if she told you that she fell and that it was an accident. ${ }^{20}$ The ignorance condition is more nuanced.

This condition is based upon a distinction that Aristotle draws in his theory of decision between "universals" and "particulars." Aristotle often explicates a decision as a quasi-syllogism, whose first "premise" can be understood as an imperative thought

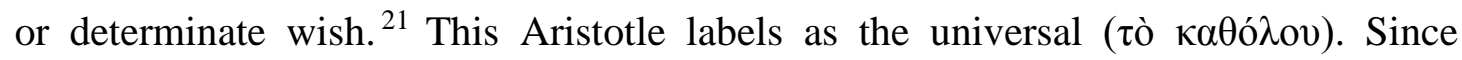
universals are necessary for practical thought quite generally on Aristotle's model, I shall only be concerned with those universals that have ethical content, i.e. content that orders agents to conform in general to a conception of one or more of the virtues. ${ }^{22}$ In

mixed-action situation (e.g. throwing cargo overboard), something remains that is choiceworthy to the agent (e.g. saving one's life) at the time, which allows the action to be described as voluntary. See Karen Margrethe Nielson, "Dirtying Aristotle's Hands? Aristotle's Analysis of 'Mixed Acts' in the Nicomachean Ethics III, 1," Phronesis 52 (2007): 270-300.

${ }^{20}$ See $N E$ 5.8, 1135a27-28.

${ }^{21}$ That some wishes are identical to the "first premise" of a practical syllogism is controversial, but it has found favor in recent years. It is implicitly accepted by Susan Sauvé Meyer, Aristotle on Moral Responsibility: Character and Cause (Oxford: Oxford University Press, 2011), 25, and has been given a strong defense by Jessica Moss, "Virtue Makes the Goal Right': Virtue and Phronesis in Aristotle's Ethics," Phronesis 56 (2011): 204-61, at 246. See NE 3.3, 1113a10-12.

${ }^{22}$ Pace John McDowell, "Virtue and Reason," in R. Crisp and M. Slote (eds), Virtue Ethics (Oxford: Oxford University Press, 1998): 141-62, at 148. I take it that, whilst the decision procedure that leads to a virtuous action is not "codifiable", a wish serving as a first premise in a practical syllogism is. See Rosalind Hursthouse, On Virtue Ethics (Oxford: Oxford University Press, 1999), 39-42. NE 6.5, 1140a25-8 strongly suggests that the experience of particular ways of acting ethically is epistemically prior to a very general conception of the good. See Myles Burnyeat, "Aristotle on Learning to be Good," in Essays on Aristotle's Ethics, ed. A. Rorty (Berkeley: University of California Press, 1980): 69-92, and David DeMoss, “Acquiring Ethical Ends," Ancient Philosophy 10 (1990): 63-79. 
what follows, I shall refer to such premises indifferently as "ethical universals," "ethical beliefs," or "ethical wishes."

In Aristotle's account, one's first ethical wish, which amounts to the general intention to do some ethical act of kind $K$ (e.g. "Persons ought to be generous"), is then followed by the thinking (or perceiving) of some secondary "premises" about situational particulars. Such secondary premises might be the thoughts (or perceptions) that: "I'm a person," and, "I have extra money to give," and "Sam needs money to buy a car." Once these premises are connected by practical reason, Aristotle thinks, action (e.g. giving money), in some form or fashion, ${ }^{23}$ usually follows. ${ }^{24}$ Of these elements, it is the first premise - the ethical universal — that is most important in terms of ethical evaluation, for in essence it already contains one's future decisions (e.g. that one will be generous) in an indeterminate form.

Aristotle's ignorance condition for involuntary action comes into play when an agent has an ethical wish about what course of action to pursue, but is unaware of the particulars ( $\tau \grave{\alpha} \kappa \alpha \theta^{\prime}$ '̌ $\left.\kappa \alpha \sigma \tau \alpha\right)$ of the situation, and so is unable to see how the rule applies. For instance, someone might hold the ethical belief that, "People should not cause offense to those who host them as guests," but, being a guest at the house of a religious person one night, she might offend her host by eating before grace is said. These sorts of actions meet the ignorance condition for involuntary action. For this reason, our irreligious eater could be forgiven for the offence that resulted from her action on the ground that she "involuntarily" ate before grace.

In general, Aristotle claims that, in order to meet the ignorance condition for involuntary action, an agent must: (1) have a universal ethical wish that she wishes to

${ }^{23}$ When it does not follow is when the agent is akratic. I discuss this case below.

${ }^{24}$ Aristotle's clearest statement of this form of reasoning is De Motu Animalium 7, 701a6-16. See NE 7.3, 1147a25-31. 
apply (or an intention that could be verbalized as such), and (2) be unaware (or ignorant) at the time of the action of either (a) herself, (b) what she is doing, (c) to what or whom the action is done, or sometimes, (d) the instrument of the action, or (e) in what way she is doing the action. ${ }^{25}$ When agents perform ethically evaluable acts that meet (1) and (2), Aristotle thinks they are possible candidates for forgiveness. In our religious case, we could say that the agent was unaware of the way she was doing her eating, namely, before the host said grace. For Aristotle, and for us, this would count as a reason for forgiving her.

V.

Forgiveness and Pain and Regret. However, this is not the end of Aristotle's description of involuntary action and the conditions under which forgiveness is appropriate. In a departure from the Eudemian Ethics, in the Nicomachean Ethics, he adds a new temporal and emotional requirement to the ignorance condition. He argues that, strictly speaking, for an action to count as involuntary, and thus merit consideration for forgiveness, not only must the agent be ignorant of one or more of the relevant situational particulars, but also, the agent must experience pain and regret when she becomes aware of those previously unknown situational particulars. For example, if Sue discovers after dinner with Bob that the food she prepared for him contained ingredients that he is violently allergic to, and which end up harming him, for her act to be considered involuntary, Sue must become upset upon finding this out, and wish she had not done this action. ${ }^{26}$ Call this the pain and regret condition. Aristotle explains:

${ }^{25} N E$ 3.1, 1111a3-6. At $N E$ 5.9, 1136a3-5, Aristotle adds to this list the particular, "against the wish of the victim."

${ }^{26}$ Pace Jennifer Whiting, who, in her "Comments on Susan Sauvé's 'Why Involuntary Actions are Painful,", Southern Journal of Philosophy 27 (1988): 159-67, at 164-65, claims that, in adding what I have called the "pain and regret condition," 


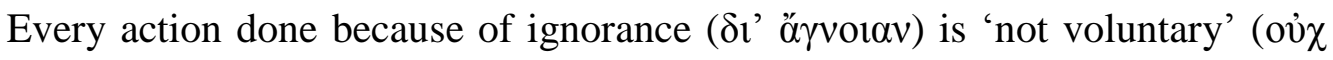

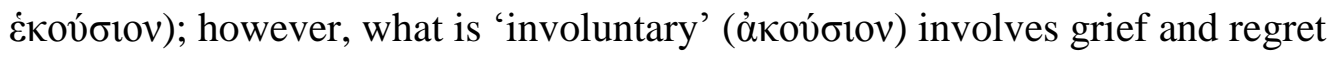
( but that person now feels no disgust $(\delta v \sigma \chi \varepsilon \rho \alpha i v \omega v)$ about this action, neither

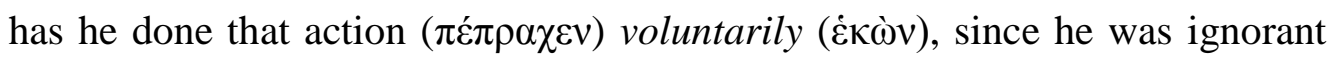
[sc. of some particular concerning the action], nor again has he done it

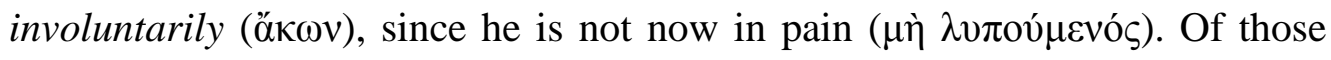
persons who act because of ignorance, the one who is now in a state of regret seems to be an involuntary agent, whilst the one who now experiences no regrets, since he is different, should be called 'non-willing' (ở $\chi \dot{\varepsilon} \kappa \omega ́ v)$, since he is different from the regretful person. Since he differs, let him be designated by a different name. (NE 3.1, 1110b18-24) ${ }^{27}$

Aristotle's use of the perfect tense to refer to the action ( $\pi \varepsilon \dot{\varepsilon} \rho \rho \alpha \chi v)$, and his use of the

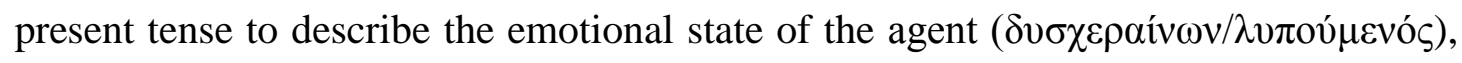
shows that the situation that he has in mind is different from that of his "mixed" actions, in which people knowingly perform painful actions that they would not do voluntarily without qualification (such as in the case of frustrated sailors who must toss overboard their cargo to survive a violent storm). ${ }^{28}$ No ignorance is involved in such mixed actions. Instead, Aristotle is interested in the phenomenon of people who

"[...] Aristotle simply forgets that ignorance allows not only that the agent perform actions contrary to her own internal impulses but also that she do so without suffering pain and regret."

${ }^{27}$ All translations are my own.

${ }^{28}$ This point is also noted by Javier Echeñique, Aristotle's Ethics and Ethical Responsibility (Cambridge: Cambridge University Press, 2012), 176-77. 
unintentionally do something bad, but upon finding out about that bad thing, simply do not care.

Take the example of a man who, whilst driving at night, bumps into something on the road, and later finds out that he ran over his neighbor's dog. Using Aristotle's distinction, the man who feels no regret for his physical involvement in this incident would be considered to have non-willingly caused the death of the dog; conversely, if he feels horrified that he had run over the dog, he would be considered to have involuntarily done so. ${ }^{29}$

Why does Aristotle take the time to point out this distinction between involuntary action and non-willed action $?^{30}$ The answer, it seems, is that he thought that lack of pain and regret in a non-willing agent who is physically responsible for a harmful action are signs that that person is in a vicious ethical state. If so, by the pain and regret condition, such a person will not count as an involuntary agent, and hence, strictly speaking, is not a candidate for forgiveness. ${ }^{31}$ This is so despite the fact that the agent performed the act "through ignorance" of the particulars.

Our moral experience does reflect this distinction. To return to my earlier example, someone who trips down the stairs and accidentally knocks you down, but

${ }^{29}$ However, what if the man who ran over the dog became positively delighted after having found this out? Should we consider him to have acted voluntarily? Logically, the answer is no. He would still count as "non-willing," because he was unaware of the particulars involved, which is a necessary condition of voluntary action. However, we could judge him as having a more vicious character than a person who felt nothing. Even so, this need not imply that the non-pained agent necessarily would have run over the dog if, counter-factually, he was aware of the situational particulars, as Susan Sauvé, "Why Involuntary Actions are Painful," Southern Journal of Philosophy 27 (1988): 127-58, at 137, rightly notes. He may, however, be more inclined to do so.

${ }^{30}$ On the importance of this distinction to the understanding of $N E 3.1$, see Rosalind Hursthouse, "Acting and Feeling in Character: Nicomachean Ethics 3.i," Phronesis 29 (1984): 252-66, and Sauvé, "Involuntary Actions."

${ }^{31}$ See Terence Irwin, Aristotle's First Principles. Oxford: Clarendon Press, 2002), 342-3. 
does not feel the sort of painful embarrassment that leads to an apology, might lead you to desire some form of payback, even if you know that this person was ignorant of the particulars of the situation (e.g. the high step), and forced by gravity to fall. Aristotle's pain and regret condition for involuntary action asserts that, for agents to be forgivable, they must not only either have been forced to be involved in some event, or to have acted from ignorance; they also must not be in a vicious state, i.e. not disposed to do such acts. If so, then Aristotle must think that the expression of pain and regret serve primarily as signs that someone is not in a vicious state after being involved in a vicious action. ${ }^{32}$ Call this class of involuntary agents, able to experience pain and regret over their actions, regretful ignorant agents.

VI.

Forgiveness for Voluntary Actions. However, regretful ignorant agents are not the only agents who Aristotle thinks are forgivable, for he does not think that it is necessary for agents to act involuntarily — at the time of commission —in order for them to be forgivable. This is because he thinks that some (but not all) acts of $\alpha \kappa \rho \alpha \sigma i ́ \alpha-$ which acts he classes as voluntary ${ }^{33}$ - are forgivable.

In $N E$ 7.7, Aristotle makes the remarkable claim that akratic agents who act voluntarily but are overcome by excessive pleasures and pains that cause them to do

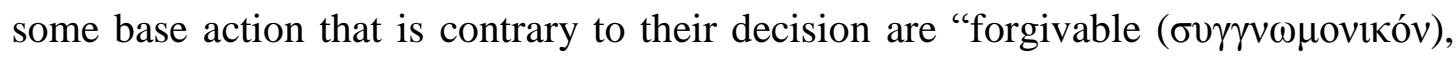
provided that they strain against ( $\dot{\alpha} v \tau \imath \tau \varepsilon i v \omega v)$ those feelings." 34 The agents Aristotle has

32 This closely parallels Williams' ("Moral Luck," 27) depiction of "agentregret," which he notes, "can extend beyond what one intentionally did to almost anything for which one was causally responsible in virtue of something one intentionally did."

${ }^{33} N E 7.10,1152 \mathrm{a} 15$.

${ }^{34} N E 7.7,1150 \mathrm{~b} 5-12$. This criterion might seem only to apply to Aristotle's "weak" akratic person, as opposed to the "impetuous akratic," who is described at $N E$ 7.7, 1150b19-28 as having acted "without deliberation." However, presumably, Aristotle thinks that, although the impetuous akratic does not deliberate at the moment 
in mind here are not the same as those agents whom he classifies in $N E 3.1$ as forgivable because their acts were caused by conditions that "overstrain (i் $\varepsilon \rho \tau \varepsilon i ́ v \varepsilon ı)$ human nature." ${ }^{\prime 35}$ This is because he assumes that agents in overstraining situations are those

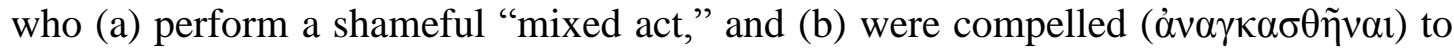
do so on the basis of external conditions or limited options (e.g. under severe torture) ${ }^{36}$ Akratic agents meet neither of these criteria.

Unfortunately, Aristotle's examples of such agents, Theodectes' character Philoctetes performing some base action after being bit by a snake, and Carcinus' character Cercyon struggling against doing something immoral in his play Alope, along with Xenophantus failing to restrain his laughter in some inappropriate situation, are not helpful in illustrating why they are forgivable. In part, this is because the dramatic works to which Aristotle refers are not extant. However, the principle that Aristotle relies upon in order to justify forgiveness in these instances is recoverable: it is the agent's ethical decision, in virtue of which she struggles against the pains and pleasures that pull her towards base actions that warrant our forgiveness. Call these forgivable agents akratic strugglers. ${ }^{37}$

Since Aristotle affirms that both classes of agents, regretful ignorant agents and akratic strugglers, are forgivable, he must be assuming a criterion for being forgivable

of action (as the weak akratic does), she has deliberated and decided upon a virtuous course of action at some point prior to entering the situation which provokes her anger. I thank an anonymous referee for this point.

${ }^{35} N E$ 3.1, 1110a23-26.

${ }^{36} N E$ 3.1, 1110a26-27.

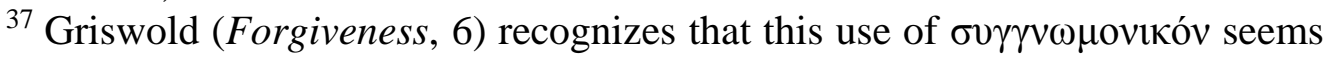
"positioned between excuse and forgiveness," but thinks it is better to rule out the latter only because he thinks that forgiveness can only be granted by the directly wronged party. However, nothing in this context decisively suggests that Aristotle has such a "third-party" view in mind, and it is doubtful that forgiveness cannot be given by a third-party anyway. 
that covers agents of both voluntary and involuntary actions. The following is a plausible criterion (although we will see later that it is in need of revision):

Forgivability Criterion (FC): An agent, $A$, is forgivable for performing a base action, $B$, iff (i) $A$ did $B$ voluntarily or involuntary, but (ii) prior to $A$ 's committal of $B, A$ made an ethical decision not to do $B$-type actions, based upon $A$ 's cognitive-affection disposition towards an ethical universal, $U$, and (iii) in virtue of possessing $U, A$ has made an effort not to do $B$, and (iv), after deliberative reflection, $A$ expresses pain and regret $^{38}$ about doing $B$.

Apart from the dramatic examples referred to above, further evidence that forgiveness targets a prior decision (which is not the same as what an agent ends up doing voluntarily) can be found in Aristotle's discussion of the ethical "curability" of the akratic agent versus the vicious agent. Aristotle claims that agents able to experience regret ( $\mu \varepsilon \tau \alpha \mu \varepsilon \lambda \eta \tau \imath \kappa o ́ s)$ over their wrongdoing in the sphere of temperance are to be

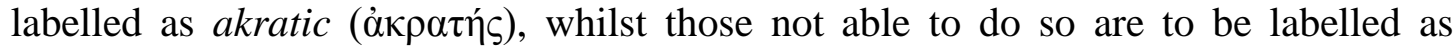

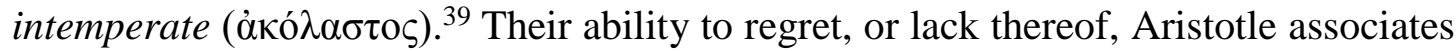
with being ethically curable, i.e. being able to progress from vice to virtue, and he associates their curability with their ethical decisions. He explains:

${ }^{38}$ Although I do not emphasize it here, it is consistent with Aristotle's position that the mental state of regret in a wrongdoer entails that she wishes to make reparation to her victim insofar as this is possible. For instance, it would not make sense to describe someone as feeling regret for stealing a car if that person did not both wish and attempt to return it to its owner. I thank Richard Swinburne for this point.

${ }^{39} N E$ 7.8, 1150b29-31. David Roochnik, "Aristotle's Account of the Vicious: A Forgivable Inconsistency," History of Philosophy Quarterly 24.3 (2007): 207-20, at 208, notes: "Even when [the akratic] does wrong, after (meta) the fact he reveals that he cares (melein) about doing what is right. For this reason he is not genuinely vicious $[\ldots] . "$ 
But the intemperate person, just as we said, is not capable of regret (ou

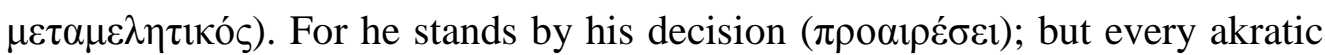
person is capable of regret. It is for this reason that the truth of the matter [ $s c$. about whether the akratic or the intemperate is the more vicious] is not what was implied when we raised the puzzles; the truth is really this: the intemperate

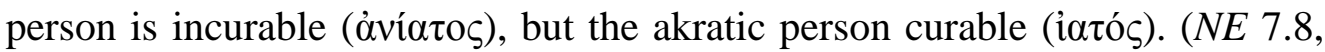
$1150 \mathrm{~b} 29-32)$

Aristotle here sets up a contrast between (a) an intemperate person who stands by her decision to have done $B$, and experiences no pain and regret over it, and (b) an akratic person, who does $B$ contrary to her decision, and afterwards does experience pain and regret about it. On what grounds, however, does the decision of the akratic person allow her to regret $B$ and be curable, whilst the decision of the vicious person does not $?^{40}$ As we have seen, the explanation cannot be that the akratic person acts involuntarily and the vicious person voluntarily.

Aristotle's explanation is that the vicious person, although she is like the akratic person in not being ignorant of any of the particulars of her action, is, unlike the akratic person, ignorant of one or more of the ethical universals pertaining to her action. ${ }^{41} \mathrm{In}$ fact, Aristotle makes it clear in NE 3.1 that it is being ignorant of such ethical universals that is the root explanation for why someone is vicious. He writes:

${ }^{40}$ See Terence Irwin, "Vice and Reason," The Journal of Ethics 5.1 (2001): 7397 , at 78 .

${ }^{41}$ See $N E 7.3,1147 \mathrm{a} 31-35$. 
So every vicious person is ignorant ( $\dot{\alpha} \gamma v 0 \varepsilon \tilde{\imath})$ of that which one ought to do and of the things which one ought to abstain from, and because of this error he becomes unjust and vicious ( $\mu$ $\chi \theta \eta \rho$ ò $\varsigma$ ) in general. But we do not want to say that an action is involuntary in cases where someone is ignorant of the things that are beneficial ( $\tau \grave{\alpha} \sigma u \mu \varphi \varepsilon ́ \rho o v \tau \alpha)$. For it is not ignorance which belongs to the choice ( $\pi \rho 0 \alpha \imath \varepsilon \varepsilon \sigma \varepsilon \imath)$ which is the cause of involuntary action; rather, this is the cause of vice; nor is it ignorance of the universal ( $\dot{\eta} \kappa \alpha \theta$ ó $\lambda \mathrm{ov}$ ) (for we are, in fact, blamed because of this ignorance), but the cause is ignorance in respect of the particulars ( $\left.\dot{\eta} \kappa \alpha \theta^{\prime} \tilde{\varepsilon} \kappa \alpha \sigma \tau \alpha\right)$, with which things and concerning which things the action consists; for with such things there is pity and forgiveness. (NE 3.1, $1110 \mathrm{~b} 28-1111 \mathrm{a} 2)$

As we shall see, Aristotle's claim that someone who acts through ignorance of the universal cannot be considered to have acted involuntarily is problematic. However, the connection between the curability of akratic persons and the incurability of vicious persons is clear: Aristotle considers ethical curability to be based in the possession of an ethical universal that facilities the expression of pain and regret, and ethical incurability to be based upon its absence.

\section{VII.}

Ethical Universals, Decision, and Pain and Regret. The absence of some universals, however, need not mean an absence of all of them. Aristotle's theory of practical decision implies that vicious people must make their unethical decisions based upon some universal first premise: in this case, a non-ethical or vicious universal. If "right reason" is the ethical universal that prudent people use to carry out their goals, then it is "wrong reason," or a vicious universal, that vicious people use to carry out 
theirs. It is this vicious universal, in fact, which explains why the vicious experience no pain and regret for their base actions, and why they remain "in their decision." 43 Vicious people are not, for example, those who steal because they need food to survive; they are those who steal because they believe that, in principle, stealing is good (either relatively or universally). ${ }^{44}$ This is because, whether they have thought it out explicitly or not, in principle, Aristotle's vicious person has decided in advance against any particular action which conflicts with her own desires, however base. ${ }^{45}$

To take a modern example, Aristotle would think that a religious extremist is not someone who simply performs acts of violence because she is ignorant of the ethical principle that such acts should not be done, but someone who believes that, in principle, it is good to use violence against people who do not subscribe to the religion that the

${ }^{43}$ David Bostock, Aristotle's Ethics (Oxford: Oxford University Press, 2000), 73, and Thomas Brickhouse, "Does Aristotle Have a Consistent Account of Vice?" Review of Metaphysics 57 (2003): 3-23, and others have noted that, in NE 9.4, 1166b25, Aristotle seems to contradict himself by arguing that the vicious person is "full of regrets." Roochnik, in "A Forgivable Inconsistency," argues that this inconsistency is Aristotle's attempt to make intelligible the unintelligible mental life of a vicious person. In contrast, Terence Irwin, Aristotle: Nicomachean Ethics (Hackett: Indianapolis, 1999), 292, argues that the cause of regret in vicious persons is their being unable to acquire wished for pleasures that require long-term effort, because, like akratic agents, they give in to lesser immediate pleasures. I take the latter explanation to be more plausible. See also Jozef Müller, "Aristotle on Vice," British Journal for the History of Philosophy 23.3 (2015): 459-77, at 467-8.

${ }^{44}$ William Hardie, Aristotle's Ethical Theory (Oxford: Clarendon Press, 1980), 157, writes: "A bad man is one who acts on wrong principles, who follows rules of conduct suggested by ends which are misconceived." Similarly, René Gauthier and Jean Jolif, L'Éthique à Nicomaque (Aristote, traductions et études) (Louvain: Publications universitaires, 1959), 184, claim: “[...] l'universel qu'elle ignore, c'est la proposition universelle qui sert de majeure au syllogisme de l'action, c'est la règle universelle de l'action ; le vicieux ignore qu'il faut faire le bien, il est au contraire convaincu qu'il faut faire le mal." That Aristotle implies that there are "vicious" universals is also affirmed by Julia Annas, The Morality of Happiness (Oxford: Oxford University Press, 1993), 554, and Irwin ("Vice and Reason," 78).

45 See NE 7.3, 1146b22-4; NE 7.7, 1150a19-21. Presumably, part of the "incurability" of vicious persons is their inability to be persuaded to believe in an ethical universal that would limit their pursuit of base things. 
act seeks to promote. ${ }^{46}$ That the vicious rely upon such principles is why he affirms that vice is "in accordance with decision." ${ }^{47}$ In contrast, both the regretful ignorant agent, and the akratic struggler, because they believe in ethical universals, ${ }^{48}$ are capable of reflecting upon their base actions in a way that can elicit pain, regret, and future striving against them.

\section{VIII.}

Forgiveness and Ethical Alteration. It should now be apparent that the view of forgiveness set out by FC already implies conditions (3), (4), and (5) of Griswold's account. However, it also gives a unified account of the relation between these conditions, by making ethical universals the primary cause of an offending agent's (a) commitment to ethical actions of the relevant type, (b) ability to identify the wrongness of past particular actions from the perspective of the victim, and (c) pain and regret when reflecting upon past wrongs. ${ }^{49}$

However, what FC does not allow for is the possibility that vicious persons, even penitent ones, can be forgiven for their past wrongs. This is because FC stipulates

${ }^{46}$ Müller ("Aristotle on Vice," 473) also notes such a character, but seems to think that, at worst, she would only be characterized as a "perverse" self-controlled person, stubbornly sticking by a wrong decision despite having the right feelings that pull her away from acts of extremism. His general doubt about vicious universals, I think, is based upon a conflation of Aristotle's characterization of "the many" with the vicious, and a neglect of Aristotle's discussion of universals in $N E$ 3.1.

${ }^{47} N E 7.8,1151 \mathrm{a} 7$.

${ }^{48}$ I take it that "believing in" an ethical universal is equivalent to Bernard Williams calls "having a concept," "possessing it as one's own," and "being disposed to use it in judgements with which one is identified." See Bernard Williams, "Acting as the Virtuous Person Acts," in R. Heinaman (ed.), Aristotle and Moral Realism (Boulder: Westview Press, 1995): 13-23, at $21 \mathrm{f.} 8$.

49 These criteria may also be found in Rhet. 2.3, 1380a14-16, where Aristotle claims that we grow calm towards people who admit their wrongdoing to us and feel regret over it, and that their being in pain about their wrongdoing acts as a sort of penalty ( $\delta$ í $\eta v)$ for what they have done. Contrast the view of David Konstan, "Assuaging Rage: Regret, Repentance, and Forgiveness in the Classical World," Phoenix 62: 24354. 
that the decision that makes regretful ignorant agents and akratic strugglers worthy of forgiveness must have been made based on an ethical universal possessed prior to their performance of a wrong action.

However, what would Aristotle say about vicious agents who later came to adopt an ethical universal that caused them to regret their past actions and prevent the performance of similar actions in the future? The acknowledgement of such a moral change by a wrongdoer underpins conditions (1), (2), and (6) of Griswold's account of forgiveness, and they are indeed the ones that, prima facie, seem the least Aristotelian. ${ }^{50}$ Is there any reason to think that Aristotle countenances this kind of change? The answer, I think, is "yes."

This is because Aristotle does admit that agents can change their ethical character, and he thinks that such a change has implications for virtuous relationships. This admission appears in $N E 9.3$, in a context which revolves around the question of how a virtuous person should deal with a virtuous friend, who, over the course of time, becomes vicious. Aristotle discusses this problem as follows:

But if anyone ever accepts someone as a friend on the basis of his being good, but that friend becomes vicious ( $\left.\mu \mathrm{o} \chi \emptyset \eta \rho \mathrm{y}_{\varsigma}\right)$ and also appears to be so, should one still love him as a friend? Or is this impossible, since not everything is lovable, but only what is good? Neither then is the bad lovable, and we must

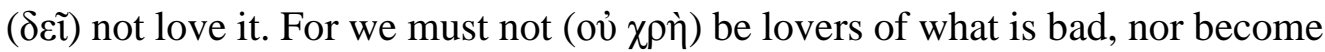
similar to someone base, and we have said that 'like is a friend to like.' So should we dissolve the friendship straightaway? Or should we not do so in every case, but only in cases where someone is incurable (ảviótorৎ) on account of his

${ }^{50}$ See Griswold, Forgiveness, 50. 
viciousness? If he is capable of being corrected ( $\dot{\varepsilon} \pi \alpha v$ ó $\rho \theta \omega \sigma \mathrm{v}),{ }^{51}$ one ought to help him recover his character $(\tilde{\hat{\eta}} \theta 0 \varsigma)$ more than his property, inasmuch as this is better and more appropriate to friendship. But it seems that someone who ends a friendship when the friend has become vicious does nothing absurd. For

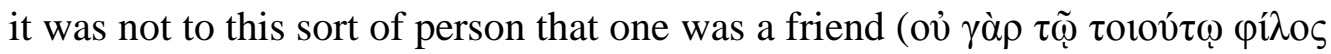
$\tilde{\eta} v)$; so, if the friend has altered ( $\dot{\alpha} \lambda \lambda \mathrm{ol} \omega \theta \dot{\varepsilon} v \tau \alpha)$ and it is impossible to restore him ( $\dot{\alpha} v \alpha \sigma \tilde{\omega} \sigma \alpha \mathrm{l})$ [sc. to virtue], one leaves him. (NE 9.3, 1165b13-22)

It goes beyond a charitable reading to suggest that Aristotle is advocating here that we should attempt to be a friend to and correct all vicious people. He gives his advice in the context of what is appropriate to particular ethical agents who have already become friends based upon their mutual goodness. However, what is not debatable is that Aristotle bases his advice on the more general principle that ethical identity ${ }^{52}$ can alter over time.

He claims that, if a formerly virtuous friend changes his fundamental orientation towards a life of virtue to become ethically vicious (importantly, Aristotle does not say "akratic"), then it is rational to end the friendship. This is because the goal of a virtuous friendship is the cultivation of virtue with another virtuous person, and this goal cannot be achieved when a virtuous person changes into a vicious one. From what we have seen above, Aristotle must hold that this alteration in character partly consists in the fact that the (formerly virtuous) friend has lost his cognitive-affective grasp of one or more of the ethical universals by which he formerly lived (perhaps by consciously choosing to ignore them bit by bit over time).

${ }^{51}$ See NE 5.10, 1137b19-24.

${ }^{52}$ I take it that, for Aristotle, ethical identity can change over time without altering personal identity. 
However, this has a striking implication for Aristotle's ethics generally, and for his account of forgiveness in particular: if he thinks that someone who has become vicious can be restored through some sort of curative process, this is only because he believes that some vicious persons can make the cognitive-affective transition into accepting the ethical universals that lead to virtue ${ }^{53}$ If so, then a question arises about the adequacy of FC. If a vicious person does become virtuous again, what sorts of ethical attitudes and actions are appropriate to this person in respect of her past actions? Continued anger? Forgiveness? Neither?

Take the example of a virtuous friend, Greg, who, after being becoming more and more of a gambler, becomes vicious and steals money from his virtuous friend, Sarah. Assume that Greg persisted in thinking that his decision to steal from Sarah was fine. If, some months later, Greg realized his error, went to treatment for gambling addiction, and resolved never to steal again, having come to believe that no one ought to steal, would it be virtuous for Sarah to forgive Greg, after he apologized to her for the acts that he did whilst in his vicious state and attempted to make reparations? Or, would it be virtuous for Sarah to continue to withhold forgiveness and bear anger towards Greg and his actions, since his past misdeeds were of a voluntary and vicious nature, and the past cannot be changed?

According to FC, Sarah should not forgive Greg, because at the time of his action, he did not have the right ethical wish, despite the fact that he now feels pain and regret and strives against his gambling addiction. However, that Aristotle acknowledges

${ }^{53}$ I use the qualifier "some" because Aristotle's example might suggest the idea that someone who becomes vicious without ever having been virtuous might not be able to alter his or her character. However, see William Bondeson, "Aristotle on Responsibility for One's Character and the Possibility of Character Change," Phronesis 19.1 (1974): 59-65, and Gianluca Muzio, "Aristotle on Improving One's Character," Phronesis 45 (2000): 205-19. 
that personal relations such as friendships can be damaged or restored, as the case may be, based on an agent's ethical alteration away from or towards virtue, suggests that this temporal qualification should be eliminated from FC. Aristotle's account of ethical alteration in our friendship passage suggests instead that it is an agent's present possession of an ethical universal, in conjunction with an acknowledgement of its application to a particular wrong, to which Aristotelian forgiveness should respond. Otherwise, it would be impossible to become friends again with persons who lapsed from virtue and caused harmed to us, given that friendship is incompatible with a desire for revenge.

IX.

Aristotle's Extended Account of Forgiveness. This account of ethical alteration strongly suggests that Aristotle is not committed to FC, but to another view, which I shall call Aristotelian Forgivability. This criterion affirms the following necessary and sufficient conditions for an agent to be forgivable for a base action:

Aristotelian Forgivability (AF) $=A$ is forgivable for a particular base action, $B$, iff (i) an agent, $A$, voluntarily or involuntarily does $B$, but (ii) $A$ possesses or comes to possess a cognitive-affective disposition towards an ethical universal, $U$, that proscribes $B$-type actions, and (iii) upon deliberative reflection, $U$ causes $A$ to express pain and regret over having done $B,{ }^{54}$ and (iv) in virtue of

54 The causal connection between $U$ and $B$ is important, since there can be cases of feeling pain and regret that are not caused by the possession of such a universal. For example, if Kant's shopkeeper regretted stealing from his customers only because it hurt his reputation for honesty, viewed instrumentally as a means to wealth, he would not be forgivable. His regret was not caused by an ethical universal, but by a pragmatic one. I thank an anonymous referee for this point. See $N E$ 3.1, 1110b11-13, and Metaphysics 5, 1015a26. 
possessing or coming to possess $U, A$ makes an ethical decision not to do $B$ type actions in the future.

This criterion, like FC, captures the forgiveness conditions that Aristotle ascribes to regretful ignorant agents (who act involuntarily), and to akratic strugglers (who act voluntarily). Both sorts of agents have a cognitive-affective disposition towards an ethical universal that tells them to do virtuous actions, and both are able to experience pain and regret in reflection over actions that are proscribed by this universal. In the case of the former sort of person, this reflection might come about when someone informs her of the situational particulars she was unaware of at the time of her action; in the case of the latter, it might come about when she reflects upon the nature of her akratic action without the interference of her more base desires, or, in the case of the impetuous akratic, calms down.

However, AF also allows something that FC does not, namely, that formerly vicious agents, whom I shall call repentant wrongdoers, can be forgivable. If the presence of pain and regret, caused by reflecting upon an ethical universal's relation to a particular case of action, alongside a decision not to do actions of the type proscribed by that universal (both now and in the future), are necessary and sufficient to make the akratic struggler forgivable ( $\sigma 0 \gamma \gamma v \omega \mu$ oviкóv), then there is no reason to think that these same conditions are not necessary and sufficient to make a repentant wrongdoer ${ }^{55}$ forgivable as well.

Even if Aristotle himself did not think there were many (or even any) repentant wrongdoers outside of the class of agents who first acquire virtue and then lapse from it, his virtue ethics provides a clear and plausible explanation for why they would be

${ }^{55}$ E.g. the vicious friend who has repented after a lapse from virtue. 
forgivable if there were. If so, Aristotle's account implies that even some vicious agents can come to meet conditions (1) and (2) in Griswold's account of forgiveness. Further, insofar as agents can provide an account of how they came to adopt such ethical universals, or how they came to possess them again, AF implies, and explains, Griswold's condition (6). For Aristotle, an agent's narrative about her vicious past this will essentially involve a story about coming to desire a higher form of happiness

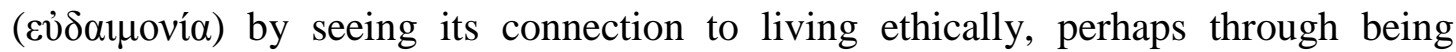
persuaded by more virtuous people, or undergoing the corrective punishment of the state.

Aristotle's account of forgiveness is also consistent with a central insight of P.F. Strawson, which is that our "reactive attitude" of resentment can change to forgiveness once an offender shows her action to be uncharacteristic of her. This is because, for Aristotle, to have a different ethical universal is to have a different character. AF implies that someone like Greg, who can express pain and regret over his past misdeeds towards Sarah, based upon a newly acquired (or re-acquired) ethical universal, can both sincerely repudiate his misdeeds, and acknowledge that his past behavior is now uncharacteristic of him. But as Strawson observes: "We shall not feel resentment against the man he is for the action done by the man he is not." ${ }^{, 56}$ This claim, which Strawson applies to ethical agents who uncharacteristically injure someone, applies equally well to ethical agents who characteristically injure someone, but later come to have a new character opposite their earlier one. Aristotle's description of ethical change implies that, if vicious people come to embrace an ethical universal which is opposed to their previous character vice, they can no longer be said to have (fully) vicious

${ }^{56}$ Peter Strawson, "Freedom and Resentment," in G. Watson (ed.), Free Will (Oxford: Oxford University Press, 2013): 72-93, at 78. 
characters, and thus cannot be associated (fully) with the injuries they caused in the past. $^{57}$

$\mathrm{X}$.

Aristotle and the Deontological Problem. Aristotle's account of forgiveness in AF goes against modern philosophical accounts that hold that forgiveness cannot be a duty because one can never reverse the blameworthy effects of an action that give an injured party the right either to withhold forgiveness, or to give it as a pure gift. Granting that forgiveness functions as a three-place predicate, namely, " $B$ forgives $G$ for having done Z," at the very least, Aristotle would deny that $B$ has reason to withhold forgiveness from $G$ in virtue of the irreversibility of $Z$ alone, ${ }^{58}$ since this leaves the role of $G$ unaccounted for. Instead, Aristotle's account suggests that if $G$ is “no longer such as to have done $Z$," then the relation between $G$ and $Z$ has fundamentally changed, and thus also the relation between $B$ and $G$. In such a case, it will be either permissible or obligatory for $B$ to forgive $G$.

The justification for this idea follows from Aristotle's account of ethical alteration and the corresponding duties of a virtuous person who is in a relationship with that altered person. If, as Aristotle says, it is impermissible to continue to love a presently vicious friend based on her past virtue-because one has a duty not to love the bad - then it should be similarly impermissible to desire to take revenge upon a repentant wrongdoer based on her past vice, given a sufficient change in the wrongdoer's character. If the repentant wrongdoer's character has changed to the extent

${ }^{57}$ Gamlund ("The Duty to Forgive," 658) argues that repentance in a wrongdoer should produce a change in how the victim assesses her, and that it would be "inappropriate" not to change one's assessment of a repentant wrongdoer. However, he does not give an explanation or a ground for this beyond the stipulation of a norm.

58 Pace Oliver Hallich, "Can the Paradox of Forgiveness Be Dissolved?" Ethical Theory and Ethical Practice 16 (2013): 999-1017, at 1005-6. 
that she can be classed as now having the same disposition as a regretful akratic, it will be permissible to forgive her, but not obligatory, since the akratic's character state is overall base for Aristotle. ${ }^{59}$ However, if the repentant wrongdoer manages to reach the dispositional state of the self-controlled person, who is classed by Aristotle as being in a good state, ${ }^{60}$ then forgiving her will be obligatory. This is because, if one has a duty not to extend one's love to bad people, one must also have a corresponding duty not to extend one's anger to good people. ${ }^{61}$

XI.

Aristotle and Kolnai's Paradox. FA also provides a way to resolve Kolnai's paradox. Aristotle's solution to the paradox is that we ought to forgive wrongdoers not when they annul and eliminate their offence (which cannot be done), but when they are expressly able to disavow the vicious universal that led them to engage in the offence in the first place. This allows a forgiving agent who accepts this dispositional change in the offender's beliefs to remain free from condoning the forgiven wrongdoer's past acts of injustice, whilst at the same time, acknowledging that something can be forgiven, namely, the changed agent.

It may of course still be rational to be angry that the offender caused an injury, but it is not rational to remain angry at the offending agent, when, ethically speaking, the forgiving agent accepts that the offending agent qua offender no longer exists. Thus, AF implies that the acknowledgement that occurs in forgiveness is the victim's

${ }^{59} N E 7.8,1151 \mathrm{a} 28$.

${ }^{60} N E 7.8,1151 \mathrm{a} 27-28$.

${ }^{61}$ However, it should be emphasized that this is a duty of virtue, which concerns dispositions to feel and act, not a general "moral duty" in the modern sense. If, for instance, one takes moral obligations to concern what one owes to someone, there is no need to accept that a victim owes forgiveness to a regretful wrongdoer. For such a notion of moral obligation, see Richard Swinburne, Responsibility and Atonement (Oxford: Oxford University Press, 1989), 74-93. 
acknowledgement that the offender has shown that she is no longer the same kind of ethical agent she once was. Forgiveness is not an acknowledgement from the victim that she will consider the wrongdoing as having never happened, nor indeed, that she was not, or no longer is, a victim of the wrongdoing. Thus, insofar as Aristotle is committed to AF, he is also committed to the idea that, if a vicious person comes to express a sufficient amount of pain and regret about their past injury to a particular agent on the basis of coming to adopt an ethical universal, the injured party's disposition to forgive that repentant wrongdoer for her admitted wrong, to the degree that the wrongdoer's character has changed, will be a virtue, and not to forgive, a vice.

XII.

Aristotle and the Moral Luck Problem. However, that AF puts this much explanatory weight on the role of ethical universals and character change may seem objectionable for a different reason. Perhaps Aristotle should modify AF to allow that ignorance of an ethical universal can sometimes be a ground for forgiving someone, especially when its possession is due to what Thomas Nagel and Bernard Williams call "moral luck." This would be a case in which an agent's possession of a vicious universal might, upon analysis, turn out to be due to factors outside her control, and hence, in some way involuntary.

For instance, it seems hard to agree that we should be angry with people who steal if they have been raised from an early age to think that stealing from the better off is justified. There seem to be clear cases in which a person's grasp of an ethical universal (or lack thereof) is due to an external cause (e.g. a bad ethics teacher, or a lack 
of resources). ${ }^{63}$ Sometimes, Aristotle himself suggests that without a guide, people will become vicious and adopt the wrong ethical views. ${ }^{64}$

However, Aristotle's ethics plausibly addresses such cases of moral luck in two respects. First, he explicitly wrestles with the possibility that moral luck might determine our grasp of ethical universals in $N E$ 3.5. Here, he responds to an objector who claims that, since we cannot control what sorts of things in the world seem to be good to us in general, we cannot be held responsible for the choices that we make that are based upon those appearances. ${ }^{65}$ Aristotle responds by claiming that we are responsible for our actions, and that our actions are prior to and produce our character, and that it is character that determines what sorts of things appear good to us. His thought might be defended along the following lines: people living in a well-governed state already have a basic grasp of virtue and vice terms, such that when they act, they are able to know whether their action will count as "acting virtuously" or "acting viciously" (even if they might not know that that sort of action will, if repeated, be habit forming and impede their ability to do otherwise in the future) ${ }^{66} \mathrm{He}$ also points out that,

${ }^{63}$ First noted by David Furley, "The Voluntary and the Compulsive, in Aristotle's Ethics and Epicurus," in Two Studies in the Greek Atomists (Princeton: Princeton University Press, 1967), 184-95, at 194.

${ }^{64}$ At $N E 4.1,1121 \mathrm{~b} 10-13$, Aristotle argues that the wasteful person will turn into a vicious character if he is without a guide, but not if he receives some care.

65 See $N E$ 3.5, 1113b31-1114a21. See also Jean Roberts, "Aristotle on Responsibility for Action and Character," Ancient Philosophy 9 (1989): 23-36.

${ }^{66} N E 3.5,1114$ a10-13. For criticism of this idea, see Haksar, "Aristotle and the Punishment of Psychopaths," Philosophy 39.150 (1964): 323-40. In defense of Aristotle, the Aristotelian commentator Aspasius, In ethica Nicomachea quae supersunt commentaria, ed. G. Heylbut, Commentaria in Aristotelem Graeca 19.1 (Berlin: Reimer, 1889): 64.2-15, identifies ignorance of the universal with ignorance of what is beneficial, and claims that we naturally hate $(\mu 1 \sigma \varepsilon i \tau \alpha)$ the ignorance that

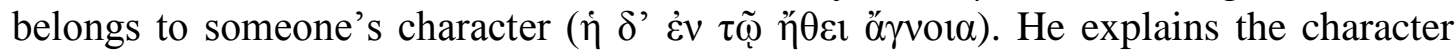
defect of being ignorant of the universal as someone's not taking care to distinguish that virtue is what is truly advantageous, and vice and injustice what are most harmful. For further defenses, see Terence Irwin, "Reason and Responsibility in Aristotle," in A. Rorty (ed.), Essays on Aristotle's Ethics. Berkeley: University of California Press, 1980): 117-55, and Gavin Lawrence, "Acquiring Character: Becoming Grown-Up," in 
if we are not responsible for how the good appears to us, then neither virtue nor vice are voluntarily acquired. The denial of this consequent, he thinks, is absurd. ${ }^{67}$

Second, and more sensitively, in cases of moral luck involving particular groups of disadvantaged people, in $N E 7.5$ he allows that certain cases of mental illness and long-term sexual abuse exclude people from normal ascriptions of praise and blame. In these sorts of cases, the kind of anger that is incompatible with forgiveness would be unwarranted. Aristotle implies, like Strawson, that we should suspend our normal attitudes and evaluations of such people, and thus not be angry with them in the first place. $^{68}$

Thus, it is clear that Aristotle has a workable solution to the problem of moral luck as it applies to forgiveness. First, he thinks that ethical agents are typically responsible for the ethical wishes they have, for otherwise the rationality of all ethical ascriptions (positive and negative) is undermined. It follows that good and bad ethical character, for the most part, is not fully subject to moral luck. ${ }^{69}$ Second, he classes as outside the scope of virtue and vice those agents who we have good reasons to think are not responsible for the ethical universals they possess, such as those who are born with cognitive defects or who have undergone abuse. Indeed, they are not appropriate subjects of anger or forgiveness at all, but of another emotion, such as pity. Thus, Aristotle does seem to hold that moral luck should be a factor in determining whether

M. Pakaluk and G. Pearson (eds.), Moral Psychology and Human Action in Aristotle (Oxford: University of Oxford Press, 2011): 233-283.

${ }^{67} N E 3.5,1114 \mathrm{~b} 3-25$. In $N E$ 1.10, Aristotle also argues that happiness does not depend on circumstantial fortunes or misfortunes, but on the (voluntary) acts of virtue.

${ }^{68}$ See $N E$ 7.5, 1148b15-1149a1, and the discussion of Sarah Broadie, Ethics with Aristotle (Oxford: Oxford University Press, 1991), 173.

${ }^{69}$ This will be so despite the fact that some virtues will be to a greater or lesser degree inaccessible to some people-some (e.g. magnificence) require extensive financial means, and others (e.g. courage) depend upon training and the opportunity to fight in battle. 
we should be angry with people who lack ethical universals because of their psychological, social, or physical history.

XIII.

Aristotle and the Unconditional Forgiveness Problem. Being forgiving then, initially counted by Aristotle as a dispositional deficiency of the character trait of mildness ( $\pi \rho \alpha o ́ \tau \eta \varsigma)$, turns out to be so only because mildness itself is the virtue that tells us when, and in what situations, particular acts of forgiveness are appropriate. Insofar as not being angry enough is a cause of forgiving too quickly, and being angry for too long — such as after an agent has ethically changed and expressed pain and regret over their past wrongs - is a cause for forgiving too slowly, it seems that the person of mild character will be the person disposed to forgive (a) regretful ignorant agents, (b) akratic strugglers, and (c) those who have committed vicious voluntary actions, but become repentant wrongdoers. In Aristotelian language, forgivingness and mildness are the same virtue, but different in account. The motivation for forgiving each of (a)-(c) is the mild person's recognition of a cognitive-affective disposition in the offending agent towards the right ethical universal, and that agent's regretful and painful admission that this ethical universal proscribes her past actions. ${ }^{70}$

If so, then it is clear how Aristotelian forgiveness answers the unconditional forgiveness problem. For an unconditional theory of forgiveness to be even remotely

${ }^{70}$ Griswold (Forgiveness, 17-18) comes near to recognizing this as Aristotle's view when he rightly classifies the disposition to forgive (in his sense) as a "mean" between the deficiency of "slavish" anger and its excess (remaining unforgiving), despite the fact that these just are the characteristics that Aristotle ascribes to mildness. His denial that mildness implies forgiveness, I think, is based upon the claim that we should interpret Aristotle's ideal virtuous person through the narrow lens of the single virtue of magnanimity, which he alleges is incompatible with forgiveness, and the claim that Aristotle's magnanimous person is relevantly similar to the Stoic stage. However, neither claim is warranted. See Howard Curzer, Aristotle and the Virtues (Oxford: Oxford University Press, 2012), 162, for further criticism. 
Aristotelian, the forgiving agent would have to hold that every vicious person or wrongdoing agent who committed some base action $B$, would, in some counter-factual situation, (1) acquire a cognitive-affective disposition towards an ethical universal that proscribed $B,(2)$ experience pain and regret over $B$, and (3) strive against $B$-type actions in the future. Such a view seems to be equivalent to the one that Plato advocates in the Protagoras and Gorgias, that no one ever does wrong voluntarily, because agents always perform the action that seems to be best to them in the situation (the implication being that they would perform the moral action that is best if they knew that it was the best) ${ }^{71}$ However, this amounts to the view that every ethical agent is naturally disposed to form correct ethical wishes unless prevented by some form of moral luck. ${ }^{72}$ However, as we have seen, Aristotle only allows moral luck to operate in a limited way in regards to our ethical wishes, namely, upon agents whom he excludes from normal ascriptions of virtue and vice.

\section{XIV.}

Conclusion. Although Aristotle himself did not articulate a theory of forgiveness as such, it is clear that his treatment of $\sigma v \gamma \gamma v \omega$ $\mu \eta$ and mildness in the Nicomachean Ethics and the Rhetoric, when seen in conjunction with his theory of ethical decision, involuntary action, and character alteration, commits him to one. AF, I have argued, plausibly captures the necessary and sufficient conditions claimed by this theory to make someone forgivable. Not only is this theory modern, in Griswold's sense, but also, AF provides a plausible account of when and why it would be virtuous to forgive, and vicious not to. AF implies that the reasons for forgiving anyone for a wrong action are the same: the presence of a transformative ethical universal that, once

${ }^{71}$ Protagoras 352a-358d; Gorgias 466a-468e. See also Laws 9, 860d.

${ }^{72}$ For instance, if it is logically necessary for fully rational beings to will ethical universals, as Kant thought. 
reflected upon, causes pain and regret over past base actions, and underpins striving against such actions in the future.

A further strength of AF is that it is flexible enough to explain how it is possible for people to forgive one another even for the most egregious of vicious acts, as long as ethical alteration and striving for the better occurs in the offending agent. This is because AF posits a shared rational and emotional ground upon which reconciliation between parties can be achieved, namely, an ethical universal that allows both parties to understand and experience a particular vicious action as vicious, and which marks the repudiation of the vicious universal in the injuring party that motivated the wrong action in the first place. This cognitive and affective idea is in fact accurately captured in the literal meaning of $\sigma v \gamma \gamma v \omega ́ \mu \eta$ as "recognize-with."

Finally, Aristotle's account of forgiveness in AF is unique because it suggests that the anger we bear towards agents who harm or slight us is not based fundamentally upon our evaluation of the badness of their acts, or in the fact that those acts cannot be reversed. Instead, it suggests that our anger at being wronged rests ultimately upon our assumption that a wrongdoer's practical reason is in a vicious state, and the assumption that this state, with effort, could have been, or can be, changed. On this account, it follows that, when we forgive we do not simply agree to forget the wrongdoer's offence; neither do we simply promise to treat the wrongdoer as if she had not committed one; instead, we acknowledge that the source of the offender's past vicious action, namely, her ethical decision, would no longer be made by her, given her change in character and ethical belief. To acknowledge this change in a wrongdoer is to deem her unworthy of anger, and is identical to the act of forgiveness.

Exeter College, University of Oxford United Kingdom 